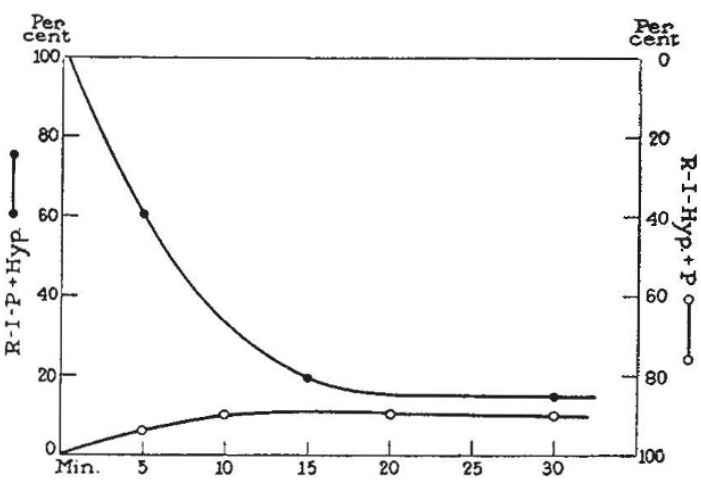

Fig. 2. EQUILIBRIUM BETWEEN A PURINE-RIBOSIDE $(R-I-H y p)$ AND THE PHOSPHO-RIBOSIDE (RIBOSE-1-PHOSPHATE, $R-I-P$ ). ENZYME : NUCLEOSIDE PHOSPHORYLASE FROM RAT LIVER. SCBSTRATE: U ORDINATE) OR OF $R-I-H y p$ AND $P$ (RIGHT ORDINATE). COMPONENTS REACTING. ABSCISSA: INCUBATION TIME IN MINUTFS

the near future, by an application of the elegant technique developed recently in this field by Prof. A. R. Todd and Dr. R. J. Lythgoe.

If ribose-1-phosphate is incubated with hypoxanthine or guanine in the presence of a small amount of purified liver nucleosidase, an extensive synthesis of purine riboside takes place. The effect is par. ticularly marked with hypoxanthine. Almost 80 per cent of the hypoxanthine is incorporated as a nucleoside. The equation for this type of reaction could be formulated as follows :

ribose-1-phosphate + purine $\rightleftharpoons$ ribose-1-purine + phosphate.

The equilibrium can be studied from both sides as illustrated in Fig. 2. The reaction is actually an enzymatic exchange between phosphate and purine. A very nearly related type of reaction has recently been described by Colowick and Price ${ }^{27}$. They found an enzyme in skeletal muscle which catalyses an exchange between guanine in ribonucleic acid and inorganic phosphate. The ribose-1-phosphate in the rucleic acid is even more acid-labile than that obtained from free nucleosides. Nevertheless, it has been possible to isolate small quantities of this 'deguanized' ribonucleic acid, which might also be aalled 'phospho-nucleic acid'. The demonstration of a guanine-phosphate cycle in nucleic acid may be ixnportant for an understanding of the biological function of nucleic acids.

I have occupied the major part of my space in dealing with in vitro studies and especially enzyme studies. The reason for this is mainly because these studies have taught us the intricate mechanism of the coupled oxidations and syntheses in which phosphate seems to have such an essential role. Before I finish this account, however, it seems natural to mention the ever-increasing number of studies of phosphate metabolism in various tissues in vivo using isotopic phosphate ${ }^{28}$. By means of this technique, it has been found that some of the most important phosphoric esters in muscle and liver are being rejuvenated with great rapidity ${ }^{29,30}$. Thus, after less than half an hour, more than fifty per cent of the phosphorus in adenosine triphosphate has been rejuvenated in the resting muscle, and only about five minutes are required to effect the same d'egree of rejuvenation of the adenylpyrophosphate present in liver ${ }^{30}$. These and many other observations bear witness to the occurrence of a very rapid uptake, transfer and liberation of phosphate in the living cells. The application of the same technique in the exploration of nucleic acid metabolism has been initiated recently by a number of investigators. These studies will undoubtedly produce many more interesting results, and perhaps be able to throw some light on the relationship between nucleic acid metabolism and cellular growth.

${ }^{1}$ Harden, A., and Young, W. J., Proc. Roy. Soc., B, 77, 405 (1906) 80, 299 (1908).

2Lipmann, F., “Advances in Enzymology”, 1, 99 (Interscience Publishers, 1941).

'Warburg, O., and Christian, W., Biochem. Z., 287, 291 (1936).

Green, D. E., Needham, D. M., and Dewan, J. G., Biochem. J., 31. 2327 (1937).

${ }^{5}$ Meyerhof, O., Ohlmeyer, P., and Möhle, W., Biochem. Z., 297, 113 (1938).

6 Warburg, O., and Christian, W., Biochem. Z., 303, 40 (1939).

${ }^{7}$ Negelein, E., and Brömel, H., Biochem. Z., 303, 132 (1939).

${ }^{8}$ Bücher, Th., Naturwissen., 30, 756 (1942).

- Lipmann, F., and Tuttle, L. C., J. Biol. Chem., 153, 571 (1944).

${ }^{10}$ Koepsell, H. J., Johnson, M. J., and Meek, J. S., J. Biol. Chem. 154, 535 (1944)

"Lipmann, F., "Advances in Enzymology", 6, 265 (Interscience Publishers, 1946).

${ }^{12}$ Lardy, H. A., and Ziegler, J. A., J. Biol. Chem., 159, 343 (1945).

I3 Szent-Györgyi, A. v., Acta Physiol. Scand., 9, supp. XXV (1945).

14 Straub, F. B., Stud. Inst. Med. Chem., Szeged, 2, 3 (Basel-New York, 1942).

${ }^{15}$ Binkley, F., J. Biol. Chem., 155, 39 (1944).

${ }^{16}$ Binkley, F., Science, 102, 477 (1945).

${ }^{17}$ Kalckar, H. M., Biochem. J., 33, 631 (1939)

${ }^{18}$ Gunsalus, I. C., Bellamy, W. D., and Umbreit, W. W., J. Biol. Chem. 155,685 (1944).

${ }^{10}$ Price, W. H., Cori, C. F., and Colowick, S. P., J. Biol. Chem., 160, $633(1945)$.

${ }^{20}$ Cori, C. F., and Cori, G. T., Proc. Soc. Exp. Biol. and Med., 34, 702 (1936).

${ }^{21}$ Cori, C. F., Cori, G. T., and Green, A. A., J. Biol. Chem., 151, 39 (1943)

${ }^{22}$ Doudoroff, M., J. Biol. Chem., 151, 351 (1943),

${ }^{23}$ Hehre, E. J., and Sugg, J. Y., J. Exp. Med., 75, 339 (1942).

${ }^{24}$ Kalckar, H. M., Federation Proceedings, 4, 248 (1945).

${ }^{23}$ Klein, W., Z. physiol. Chem., 231, 125 (1935).

${ }^{28}$ Lowry, O. H., and Lopez, J. A., J. Biol. Chem., 162, 421 (1946).

${ }_{27}$ Colowick, S. P., and Price, W., Federation Proceedings, 5, 130 (1946).

${ }^{28}$ Hevesy, G., J. Chem. Soc., 1213 (1939).

${ }^{29}$ Flock, E. V., and Bollmann, J. L., J. Biol. Chem., 152, 371 (1944).

${ }^{30}$ Kalckar, H. M., Dehlinger, J., and Mehler, A., J. Biol. Chem., 154, $275(1944)$

\section{BRITISH FAMILIES EDUCATION SERVICE IN GERMANY}

\section{By F. J. DOWNS}

Deputy Director, British Families Education Service

IISTORICALLY, the British Army has always maintained a goodly proportion of its strength overseas on service away from Britain. In peace (and within living memory during war, too) it has been the right of the regular soldier on certain conditions to have his wife and family with him on foreign service. For more than a hundred years, therefore, it has largely fallen to the Army to provide schools for British children overseas.

In Germany to-day elements of the three Services and the civilian Control Commission for Germany are serving in what is officially described by the Services as a 'home station'. It is therefore appropriate that arrangements for the British children who have joined their parents in Germany should follow the pattern of educational arrangements in the United Kingdom, and for this purpose a civilian organisation, the British Families Education Service, was established. 
The British Families Education Service has taken as its mandate the implementation of the provisions of the Education Act, 1944, for all British children in Germany in so far as conditions here permit. Departmentally, its organisation is very similar to that of a local education authority in Great Britain. The B.F'E.S. policy-forming committee is regularly composed of high ranking officers representing the users of the school service (that is, the three Services and C.C.G.) and the director of the B.F.E.S., with occasional full representation by the Ministry of Education. This local "Education Committee" in Germany has become known as "The Board of Education, B.A.O.R.", and meets regularly each month to determine how best to interpret the Education Act, 1944, for British children in Germany to-day.

The implementation of agreed policy in the light of local conditions is co-ordinated by the British Families Education Service, at its headquarters offices at Herford, and effected by the regional education officers who are stationed with their staffs at each of the Control Commission Regions in the British Zone and in the British Sector, Berlin. These regional education officers, therefore, correspond to divisional education officers in Great Britain. All British teachers working with B.F.E.S. in Germany are from schools in Britain. Many have been seconded by their local education authorities at home for periods of from one to three years, and it is a widely held view that the breadth of experience the teachers will gain from the working conditions in Germany will at least partly reward the local education authorities at home for generously agreeing to secondment at a time when they are themselves in need of all their teachers. In addition to the British teachers, some Germans are employed part-time as nursery helpers and for some specialist subjects for which there are not sufficient British staff.

The H.Q. offices of the B.F.E.S. were established in Herford on September 24, 1946. Regional offices were opened and the first British teacher arrived in Germany during November 1946. Now after about nine months there are 220 teachers at work with about four thousand British children in about seventy different places. It is thus too soon to draw any but the most tentative conclusions from this first British local education authority overseas; but one or two points are worth noting.

The majority of the children arriving here from the United Kingdom are in the lower age group. Plans for the next stage of development anticipate a child population of some 10,000 , which will break down as follows : 2,000 under 3 years of age; 2,000 between 3 and 5 years of age; 4,800 between 5 and 11 years of age; $1,200,11$ years of age and over.

Thus, numerically, the problem is about the same as for a small county at home; but in Germany to-day there are additional factors which make for complication in the organisation of education for the British children. Chief of these complications is that the children are unevenly scattered throughout 20,000 square miles of territory, with outliers in the Low Countries and Berlin. In some areas there are only three or four British children, in others three or four hundred.

It will therefore be apparent that if B.F.E.S. has had to establish school groups in about seventy different places the broad pattern will be for most of the British child concentrations to be between 10 and 150 strong, with a few larger concentrations of between 150-400. In such circumstances co-education becomes a practical necessity in order to economize in teachers, equipment, materials and buildings. It will be equally apparent that whereas the nursery, infant and junior groups are usually in teachable concentrations, the effect of uneven scatter on the smaller secondary population is, locally, to leave a large number of embarrassingly small 'senior tops' to the primary groups. This very inadequate solution is naturally only acceptable as an interim means of giving education on quasi-Dalton plan lines to children of secondary school age who have been brought to Germany in advance of arrangements being made for adequate secondary education.

So the B.F.E.S. has come to the conclusion that the only way that most of the British children over 11 years of age can receive satisfactory secondary education suitable for their age, ability and aptitude is by attending boarding schools. Accordingly, on July 1, 1947, the first publicly maintained co-educational secondary boarding school was opened at Wilhelmshaven in premises recently vacated by the Royal Navy.

The B.F.E.S. Prince Rupert (Secondary) Boarding School, Wilhelmshaven, will cater for 250 boys and girls. It is calculated that at least two further boarding schools of similar size (or rather larger) will be needed to provide education for those children of secondary age who can only be offered appropriate education in boarding schools. The demand undoubtedly exists among parents, more than four hundred having applied within a week of the first. announcement about Wilhelmshaven; and further secondary schools will be established immediately B.F.E.S. is offered suitable buildings. It now seems likely that it may be possible to open a second large boarding school by Christmas. Apart from secondary education in boarding schools it has been found possible to establish a day secondary element of reasonable size in Hamburg, and necessary, because of its isolation, to have a similar secondary element in Berlin. Outside Wilhelmshaven, Hamburg and Berlin, B.F.E.S. teachers are only at the moment able to make ad hoc time-marking arrangements for children of secondary school age, and so the position will remain until further buildings are made available for secondary boarding schools.

Scattering has not complicated the establishment of primary school groups to anything like the extent that it has conditioned the basis of secondary provision. Primary groups are therefore being established to a more familiar pattern, though the school buildings on the whole are somewhat unexpected, and bear more resemblance to the conventional idea of 'private academies for young gentlefolk' charging expensive fees than to State schools charging nothing.

Scatter in most places has necessitated that British children attending day schools are collected in buses. Although distances are carefully watched, and the very young children are not allowed to travel, it is often inevitable at this stage that some children travel farther to school each day than is normally desirable. So, for economy of time and effort alone a school meals service would have been desirable in Germany to avoid a double midday journey, even were there not even stronger social training reasons for its institution. The B.F.E.S. school meals scheme for all school groups officially began early in May 1947 on a basis of container meals cooked in the nearest mess and transported to the school for the children to take their midday meal there. Later, 
as kitchens are prepared and equipped each school group will have its own cooking arrangements, as some already have.

B.F.E.S. has also instituted a school library service of several thousand volumes circulated in a hundred specially designed travelling showcases, which are used as portable lending libraries on arrival at the schools.

Now that B.F.E.S. is settling in, we are all very conscious that there is a long way to go and many problems to solve before the Education Act, 1944, is a complete reality for every British child in Germany. Books are still lamentably short, and starting as we are from scratch there are no past stocks on which to draw. There is certainly a lower limit below which book supplies should never fall; but anyone who has seen the improvisations and class teaching of B.F.E.S. teachers who can only, at the moment, be supplied with a small percentage of the books they want, may reach the conclusion that schools and school teachers have tended to put this lower limit too high. Like books, furniture and equipment is neither fully in position nor, in every case, to the requested specification of B.F.E.S.: each month, however, sees improvement.

School organisation is also seriously complicated by the movement of families, and here the Services are the chief offenders. One boy of nine, for example, had been in six different schools at various Army stations, while one B.F.E.S. school lost overnight twenty children from one regiment to receive in exchange twenty-five children from another. At the same time continual movement on any scale may well necessitate a degree of standardization of curriculum and text-books in order that the movement of children from one school to another can be accomplished as smoothly as possible. Similar standardization was forced upon Army schools, which have had continually to cope with the same problem.

It is far too early to estimate the psychological effect of residence in Germany on the British children.
It is unhappily true that values are awry here to-day, and the British child may well get a sense of power which he is ill-adapted to assume. His few sweets, for example, have appreciable 'black market' purchasing power; the eagerness to do his bidding on the part of servants at home and in the families' clubs may breed in him an unnecessary arrogance; he may find, expediency being what it is, that a German boy may be cuffed by him without hitting back. Alternatively, he may find his sympathies overplayed and his outlook distorted by the many sights that can and have done both to adults working in Germany to-day.

Nevertheless, when all possible difficulties are appreciated a great deal remains on the credit side. The British schools in Germany can provide the German people with a very positive demonstration of British education in practice in their midst; and the behaviour of our children will be watched equally with the curriculum, as the behaviour of our occupation forces is at least as important as our formal laws and ordinances. For the British children themselves there is a profound potential for good in their attending a British school in Germany to-day. They will probably emerge bi-lingual, they will have wide opportunities for exploration, and they should emerge with a wider and more elastic attitude to their work, for their real joy in being at school is very apparent. Fundamentally, the chief determinant of whether bringing the children to Germany was a good or bad thing will be the quality of the British education provided here. This, in its turn, is a reflexion not merely of the printed word of the Education Act, but also of the skill and enthusiasm of the teachers in putting it into effect in the schools.

In its teachers, B.F.E.S. has been more than fortunate, and we all hope and believe that they themselves will benefit from the experience of a stay in Germany at least in proportion to the willing and excellent service they are giving the British children in Germany to-day.

\section{NEWS and VIEWS}

\section{Hydraulic Research Organisation: Sir Claude Inglis, C.I.E.}

WrTH the appointment of Sir Claude Inglis as director of the new Hydraulic Research Organisation, the proposal to form a National Hydraulies Laboratory in Great Britain moves one more step towards realization. Sir Claude's work in India, where for many years he has been the leading exponent of the systematic use of models in the design of large civil engineering works, is known throughout the hydraulic laboratories of the world. He became director of the Central Irrigation and Hydrodynamic Research Station (now the Indian Waterways Experiment Station), Poona, in 1937, when it was taken over by the Government of India, and there, and in his previous capacity as superintendent engineer of the Research Division of the Bombay Irrigation Service, he has been responsible for the solution of a wide range of problems in river control : for example, the safeguarding, in 1934, of the Harding Bridge on the Ganges, where previously repairs alone had cost nearly a million pounds in two years, and the determ. ination of the origin and remedy for the flooding of the Indus in 1942. Earlier, as assistant engineer or as executive engineer, Sir Claude was in charge of the construction of many works, including the building and remodelling of several canal systems in the Decean. Such constructional experience should ensure that practical difficulties will be given full attention in the designs emanating from his Laboratory.

Perhaps the most important application of hydraulic work lies in the botanical and agricultural fields, and Sir Claude has had long experience in this, for in 1913 as executive engineer of the Poona Irrigation District he was reporting upon salt-saturation of soils arising from irrigation and evaporation; also at about that time he was responsible for introducing new and successful methods in connexion with land drainage and reclamation in the Deccan. His publications on hydraulics include such subjects as river meander, river training, scale effects and the use of distorted models, and he has been responsible for technical reports on very many irrigation, river and coastal works, many of which have been printed in the Annual Reports (Technical) of the Indian Water. ways Experiment Station. 